\title{
Integrated Farming Systems Approach: Increase Food Security, Agricultural Farm Income and Rural Economy
}

\author{
Anil Kumar Yadav ${ }^{1 *}$, Ramawat Nalini $^{1}$ and Singh Dashrath ${ }^{2}$ \\ ${ }^{1}$ Amity Institute of Organic Agriculture, Amity University, Noida U.P., India \\ ${ }^{2}$ Department of Agricultural Economics \& Farm Management, JNKVV, Jabalpur, M.P., India \\ *Corresponding author
}

\section{A B S T R A C T}

In India, agriculture production is a backbone of Indian economy, but in recent past

\section{Keywords}

Farming System approach,

Integrated farming

systems, Farm

household, Rural

economy

development

Article Info

Accepted:

10 January 2019

Available Online:

10 February 2019 agriculture in gross domestic product is declining 14\%, average size of land holding is gradually decrease $<0.5$ ha. However, number of operational land holdings is increasing with the pace of time. It is essential to develop strategies that enable sufficient income and employment generation, particularly for small and marginal farmers who represent approximately $>85 \%$ of the farming community. Under the continuing decrease of land holding, horizontal extension of land is not possible. For this reason, vertical integration of farm enterprises will make farming more cost-effective and reliable. Integrated farming systems proved as viable approach with an appropriate combination of farm enterprises, such as crop production, forestry, poultry, horticulture, livestock, fishery, apiculture and sericulture etc. in precise farming condition to address the problems of decreasing economic growth of our Indian farming communities. Therefore, it is viewed as a great tool for natural and human resource management in growing countries like India. This whole farming system approach is very useful in solving the problems of small and marginal farmers of India. The farming system approach is helpful in increasing the farm income and employment opening for rural population and also protects the natural resources in the course of recycling of the crop residues and animal wastes used within the farm itself. In this paper, with literature related contribution of farming systems approach in achieving food security and prolonged rural economy has been reviewed carefully.

\section{Introduction}

In India circumstances more than $60 \%$ people are engaged directly and indirectly in agriculture work. Indian agriculture has been taken the responsibility of providing food and employment to its millions of people. In era of 1960 green revolution technologies introduced by Dr. Swaminathan with the help of high yielding varieties of wheat and rice and irrigation facility as well as fertilizer use in north India especially in Haryana and Punjab. During this green revolution high dose of fertilizer are used and over a time period soil fertility reduction was reported (Sushil Kumar Patial). Green revolution also effect on sustainability of agriculture production and mark a question on national food security in long term. The size of agricultural land holding is decreasing by 
increasing Indian population as well as the expansion of urbanization and industrializations. This situation creates a serious problem in agriculture sustainability and food security. Over a period of time, researcher and farmers are more focus on crop production without consider the integrated farming system. This is a serious challenge to the stability and profitability of the agriculture production. At this time, decreasing the average land holding ( $<1$ ha) comparison to 1970 (>2 ha). If this trend will continues in future, and then in 2020 the average size of land holding would be less than 0.6 ha. and in 2030 it will go down to 0.32 ha. (Agriculture Census, 2010-11). To address this situation, we required integrated effort to fight emerging agriculture issues. It is a very important to build up good strategies and use new agricultural technologies that make possible to increase adequate income and high employment generation, usually for small and marginal farmers, because they represent $>85$ per cent of the agricultural community. For small and marginal farmer, the integrated farming system approach is measured as the great tool for enhancing the agriculture production and profitability. The integrated farming systems approach require proper planning and management, good design, well analyzed; and also all implementing for getting higher productivity, more profitability and also sustainability of the agricultural farm. These farming system are needed to be cost effective or economic viable, ecofriendly, socially acceptable and high cost benefit ratio. The Integration of agriculture farm enterprise lead to greater output than single farm enterprise based farming system. It also improves the balance diet and nutritional quality to the farmers.

\section{Means of sustainable rural livelihood}

Theoretically "livelihood" means, activities, entitlements and resources by which people make a source of revenue. Resources are, natural (land and water), social (family and society), political (contribution and empowerment), human (education, employment, health and nutrition), physical (Infrastructure like-roads, clinics, markets, schools and Public building) and economical (jobs and saving). The sustainable livelihood becomes a role of human being that how they utilize the recourses on a short and long-term basis. Sustainable livelihood is capable to deal with and make progress from natural shocks and stresses such as flood, drought, hails and civil war and government policy failure through adaptive and coping strategies (Jirli et al., 2008). Potential, fairness and sustainability these are collective in the concept of sustainable livelihood. This concept is an effort to go ahead of the conventional definition and approach to poverty eradication. Sustainable rural livelihood had been focused only certain aspect or manifestation of poverty, such as low income, or didn't consider other basic aspects of poverty such as vulnerability and social inclusion. It is recognized and more attention on various factor and process which enhance ability of poor people to make more economically, socially sound living. The Sustainable Rural Livelihood concept offers a more logical and integrated approach to poverty mitigation. To attain sustainable rural livelihoods, different livelihood capital such as natural, social, human, physical and economical would play a better role to manage with natural shocks and stresses and sustain or improve the individual capability and resources both in present and future without degrading the natural resource base.

\section{Integrated Farming System (IFS)}

FAO (1977) stated that "there is no waste", and "waste is only a misplaced resource which can become a valuable material for another product" in integrated farming system. Later on, Edwards (1997) described that the IFS as an aquaculture system that is 
integrated with livestock, where animal waste is used for fish feed. According to Okigbo (1995) that the IFS as a mixed farming system that contain minimum of two separate but reasonably inter-dependent on each other like as crop and livestock enterprises. It is a mixed animal and crop system where the animal constituent is commonly raised on agricultural waste products, while the animal is used for the ploughing purpose and also provide animal waste to be used as manure and fuel. In another words, IFS concept as a type of mixed farming system that is combines crop and livestock enterprises in a supplementary and complementary manner (Jayanthi et al., 2000; Agbonlabor et al., 2003). The difference between mixed farming and integrated farming is that farm enterprises in the integrated farming system are mutually supportive and depend on each other (Csavas, 1992). Radhammani et at., (2003) described, IFS as concept of minimize risk, increasing production and net profit along with improving the utilization of farming wastes and crop residues. The basic concept of IFS is complementary and synergies effect between animal component and crop. The combination usually occurs when the outputs (usually byproducts) of one enterprise are used as input for another enterprise within the perspective of the farming system. Mangala (2008) mentioned that integrated farming system adopted by respondents, after implementation of Integrated Farming System Programme in Dharwad, were agriculture-horticultureforestry-dairy-vermicompost (62.14\%), agriculture- horticulture-forestry- dairyvermicompost- forage crops (21.43\%), agriculture-horticulture-dairy-forage crop (7.86\%), agriculture-horticulture-forestrydairy-forage crops (5\%) and agriculturehorticulture-dairy (3.57\%). Ugwumba at al. (2010) recognized that the integrated farming systems adopted by respondents, were croplivestock (47.62\%), Crop-fish (9.52\%), cropfish-livestock (29.76\%), livestock-fish (1
$1.90 \%)$ and crop-livestock-agro processing $(1.19 \%)$.

Enterprises linked in different agroecosystem (Source: Manjunath et al., 2014)

\begin{tabular}{|l|l|l|}
\hline Dry Land & Garden Land & Wet Land \\
\hline Crops & Crops & Crops \\
\hline Dairy & Dairy & Dairy \\
\hline Poultry & Poultry & Poultry \\
\hline Goat/Sheep & Mushroom & Mushroom \\
\hline Agro Forestry & Apiary & Apiary \\
\hline Farm Pond & Piggery & Fishery \\
\hline- & Sericulture & Duckery \\
\hline
\end{tabular}

Important characteristics of integrated farming system

It is problem solving

It is holistic:-the whole farm is viewed as

a system encompassing interaction subsystem.

It acknowledges the location specificity of technology solution

It defines specific client groups

It is farmer participatory

It gives importance to indigenous technical knowledge system

It is concerned with 'bottom up' research strategy

It is dynamic

It recognizes interdependencies among multiple clients

It focuses on actual adoption and on sustainability

\section{Need of integrated farming systems}

In the changing scenario of climate change and decreasing per capita land needs holistic approaches to enhance the farm income mostly in rural agricultural belt of India. Some of the most require factors are forces to use the Integrated Farming Systems context are: 


\section{Deteriorating natural resource quality}

For the duration of post green revolution time period, effort to solve food problem through excess use of agriculture chemicals, more frequent irrigations and high cropping intensity reduced food quality through food contamination, soil ground water pollution, soil degradation and distress of beneficial micro-organisms. In many regions of country, both surface water and ground water both are becoming unfit for human and animal consumption, due to residual concentration of agro- chemical. Accessible estimates show that nearly 120 to 125 million ha of land in the India are being degraded (ref). Intensify agriculture, coupled with irrational use of irrigation water, chemical fertilizer and pesticide, particularly in irrigated area has led to adverse effect on soil health.

\section{Adverse effect of climate change on agriculture}

The continuously increase in greenhouse gases (GHG) resulted in global warming. The Inter-governmental Panel for Climate Change (IPCC) predicted an increase global temperature from 1.8 to $4.0^{\circ} \mathrm{C}$ by the end of this century. Temperature effect on ice glacier melting and increasing sea level, these changes will affects on agriculture through causing natural calamities effect directly and indirectly on crops, soils and livestock along with bio-pests and disease. The environmental changes in future is likely to be very high due to larger dependence on agriculture, more exploitation of natural resources, irrational rearing of livestock population, inappropriate land use pattern and socio-economic factors, that effect and threat in meeting the food, fiber, fuel and fodder requirements. Current studies done by the Indian Agricultural Research Institute, New Delhi, that indicate the possibility of 4 to 5 million ton wheat production reduced in future due to every rise of $1{ }^{\circ} \mathrm{C}$ temperature ref. The integrated farming system approach may be one of the possibl ways to mitigate the effect of climate change.

\section{Decline biodiversity}

The narrowing of genetic biodiversity occurs as traditional crop varieties and animal breeds these are replaced by recent one. These new varieties/breeds will definitely be coordinated to modern agriculture, but hardly ever any consideration was given to preserve the biodiversity of an agricultural ecosystem. In addition to, the monoculture farming tends to wear away the Bio-diversity of flora and fauna in present agriculture system. For example, widespread adoption of rice-wheat monoculture in Indo- Gangatic plain region has been replaced by the other traditional agricultural crops or locally grown crops. By monoculture system, Soil micro-flora is adversely affected due to intense use of agricultural chemicals and lack of crop residues recycling process. The IFS with multiple enterprises round the year, Agriculture farming is capable of realistic and towards increasing biodiversity.

\section{Diversity of integrated farming systems}

Very frequently, almost all Indian farmers adopt integrated farming system because of supplementing their need of food, fodder, fuel, fiber and earn some money. Among the agricultural activities, most of the farmer are adopting or revolving around the crop and livestock farm components. In India small and marginal farmers ( $>85 \%$ ) livelihood depends mostly on crops and livestock. which is frequently affected by weather abnormality. Under present circumstances, Integrated farming system model has many issues such as, the lack of scientifically designed farming system, economically cost-effective and socially acceptable farming systems, Farmers 
were unable to strap up the real benefits through integration of farming system. A very important outcome of this Farming system that is their farming activities carry on regularly at large with subsistent in nature rather than commercial and several time proved un-economical.
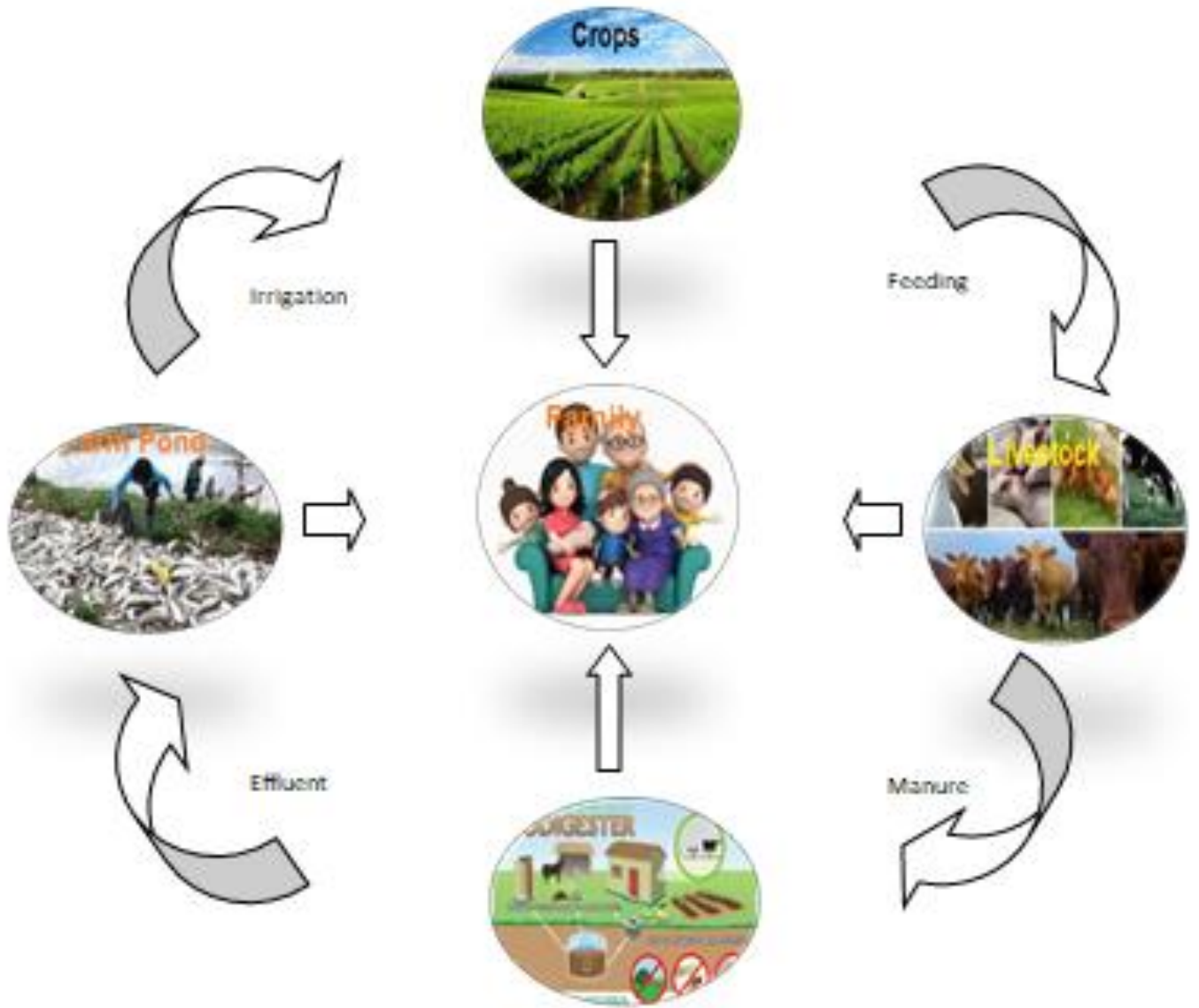

\section{Integration pathway in (Ecological) Integrated farming system}

Low rate of farm resource recycling process

Farmers don't have adequate knowledge about techniques and benefits of recourse recycling like as households waste, organic wastes in agriculture farm. A huge unused material exists to recycle (these organic wastes are farm origin). If farmer recycle the crop residue and farm waste that may be more potential of organic source to maintain and increase the soil health. Recycling of crops residue may be a more potential of organic source to sustain the soil health. Crop residues of preceding crop (legume crop residue) are recycling in succeeding crop (Cereal crop) to maintain the physiochemical properties of soil and also increase the nutrient uptake by crop and ensure better soil environment for crop growth.

\section{Gap in technology adaptation}

The advancement new and existing technologies, the involvement of people in implementing and transfer of these technologies would be very important. The farmer family had never been the crucial point 
of our investigations. The top to down approach of investigation of finding gaps, problem and tried to solve. At state and national levels lack of poor extension education cannot spread the idea of new technology, many farmers who are actually benefited that they remain unaware about many of the govt. developmental schemes and policies. So that the ideal impact of such schemes are not getting by many farmer. One of the main reasons for low rate of transfer of agricultural new technologies is poor linkages, communication gap between the different groups such as farmers, service providers, technological and financial institutions and Government are either inactive or absent (NAAS, 2009). The continuous crops production without adding outside inputs that reduces the ability of the soil reserve base which results in declining crop productivity (Willett 1995; Craswell 1998; Limpinuntana et al., 2001; Noble and Ruaysoongnern 2002). However, growing risk of crop failure due to a range of factor for example disease, drought etc. which demonstrate farmers to a high degree of variability in yield (Reijntjes et al., 1992; Ashby 2001). Further, some Scholar indicated that commercial farming systems are a risk to the environment by a loss of genetic diversity and the probable negative impacts of these systems and their allied inputs (Ashby, 2001). Single farm enterprise is not being able to uphold the small and marginal farmers without implement the integrated farming systems, for the making of enough income and productive employment (Mahapatra, 1992). At this time populations increasing continuously but agriculture land are a limited sources and the usual shrinking of land holding. it is very necessary to use limited land with integrate land based enterprises like Animal husbandry, fishery, poultry, apiculture, sericulture, forestry along with field crops and horticultural crops etc. within the bio - physical and socio - economic atmosphere of the farmers to make farming more profitable and reliable (Behera et al., 2004). The beneficiaries who have potential mainly small farmers often do not adopt new technologies due to various reasons (Raman and Balaguru, 1992). A number the major reasons for less adoption of new technologies are:

* Lack of awareness about the new technology,

* Ineffective extension services such as publishing, media, illiteracy and ignorance, inappropriateness of the technology due to local conditions,

* Lack of resources to invest on the required inputs,

* Lack of availability of inputs in time,

* Lack of farmer's participation in designing the technologies, 7. High initial cost and skill oriented technologies.

The fundamental aim of IFS is to obtain a set of resource development and utilization practices, which lead to ample and persistent increase in agricultural production (Kumar and Jain, 2005). Therefore, integrated farming systems are frequently view as a sustainable substitute of commercial farming systems mostly on small and marginal farmer lands with the main objective of resource recycling and increasing farm income. A survey held in country as whole; in farming system the milch animals have major priority in place of breed and productivity, and the milch animals have first choice of the farmers as an important and integral part of their farming. On the other hand, from economic point of view, vegetables and fruits followed by livestock production are the most established components of the farming systems in the country. Integrated farming system has many success stories in various part of country that suggested the farmers to increase their net farm income by the means of integration of different farm enterprises in a farming system. 
Integrated farming system vis-a-vis sustainable rural livelihood security

Lightfoot and Minnick (1991) reported that the integration of forest trees into agricultural system offered financial security and ecological balance and environment protection. Use of various plants and animals, expend possible sources of income and employment generation. The production of wastes and byproducts of one enterprise was used in other enterprises. In this manner, the need for external inputs is reduced such as feeds and crop nutrients (Csavas 1992, Little and Edwards, 2003). Livestock enterprise on a farm provided inputs (compost) to other enterprises (crop) and production of meat and milk, the earnings of income, savings and enhance social status (Schierre et al., 2002; Little and Edwards, 2003). Diversification of agricultural farming and their activities enhanced the utilization of labor, decreased unemployment rate in area where the availability of number of labor is more, and provided a regular source of income for living those households that operated their farm as a full time occupation (Thamrongwarangkul 2001; Van et al., 2003). Liyanage et al., (1993) observed that the combination of legume-based pasture and dairy animal indicated that the coconut, palms in the integrated system yielded above $17 \%$ more nuts and $11 \%$ more copra. While sustain the nutrient status of the palm above the critical level, in spite of reduced application of fertilizer. Nutrients returned from 73-74 kg of fresh manure and 30-32 liters of urine/palm/year reduced the cost of fertilizer needs by $69-70 \%$. In the context of the animals, there was sufficient forage to promote 305 to 590 grams/head live weight and increase 3 to 8 liters of milk/day during the first lactation period. The integrated farming system approach is sustainable, economically viable and eco friendly compare to monoculture system. De Jong and
Ariaratne (1994) indicated that dairy contributed to the total gross margin of the 0.2 ha, 0.4 ha and 0.8 ha units of 31,63 and $69 \%$, correspondingly, followed by crops (29\%, $37 \%$ and $19 \%)$, than poultry $(22 \%, 0 \%$ and 9\%), and goats (18\%, 0\% and 3\%). Dairies and goats proved to be attractive more cash earners with a high labour productivity and also high capital requirement. While dairy animal and goat manure are used to improve soil health by increasing soil fertility and productivity and animal slurry are used for biogas, to replace domestic fuel and save environment were important benefits. Poultry also play important little role to improve farm income. Singh et al., 1993 explain that economic analysis of different farming systems ( 1 ha of irrigated land or 1.5 ha of unirrigated land) show that under irrigated conditions- mixed farming with high cross breed cows indicated the maximum net profit followed by mixed farming with buffalo and arable farming. If mixed farming with Haryana cows made a less net profit. Kumar et al., (1994) revealed that the relative productivity and economics of dairy enterprises (mixed farming with 3 crossbred cows on 1 ha of canal irrigated land vs. mixed farming with 3 Murrah breed buffaloes) show that mixed farming with cross breed cows under canal irrigated conditions was more efficient for the utilization of the resources of the farmer such as land, labour, capital and inputs. They also studied the financial viability of a poultry and fish culture system and concluded that under the current conditions, higher incomes and on farm labor consumption can be found by integrating different enterprises on the farm. Rangasamy et al., (1996) studied the integration of poultry, fish and mushroom with rice cultivation over a 5 year period. This study concluded that the integrated farming system with included the above mention three components increased net farm income along with on farm labour employment when 
compared with the usual rice cropping system. Radhamani et al., (2003) explain after the studies of various research papers and reviewed that the financial viability of integrated farming system. He concluded that various components of farming system positively influenced the economic viability of these systems. The results gain from these system by structured studies that received regular inputs such as genetic resources, labour, irrigations and information are to some extent removed from reality. In the majority cases availability and uses of these inputs was variable and often depend on some factors that are away from the control of the farmer. Radhamani (2001) studied the additional employment gains 314 man days/ha/year by integrated farming system (crop + goat) under (Vertisol) rainfed. Devasenapathy et al., (1995) recognized, that integrated farming of groundnut + black gram + maize with integration of other farm enterprises such as dairy, fish, poultry and rabbit rearing and he found higher net income as compared to conventional cropping system. Ravi, 2004 confirmed that agriculture with poultry, sheep and with sericulture rearing were the important farming systems that identified in their studied area. The selected farming systems of both in small and medium farms was studied i.e. comparative profitability and it showing that the farming system like agriculture with sheep rearing was more profitable among the selected farming systems with annual net returns of 0.43 to 0.45 Lakhs per small farmer and 0.75 to 0.76 lakhs per medium farmer, respectively. Nageswaran (2009) research and studied that the five treatments of crop + dairy with 3 milch cows, crop + poultry with 6 layers, dairy with 3 milch cows cum poultry with 6 layers, improved cropping and farmers cropping both were taken alone. The management such as, In Paiyur, dairy based farming system gave the maximum income 12,180 ha/year and employment 518 man days/year. In Yercaud, dairy cum poultry farming gave the maximum income (up to 13,822 ha. per year) and employment (556 man days per year). Dwivedi (2007) concluded that economic returns from agriculture + horticultural system, that was increased by 16.5 to $136.2 \%$ over single cropping system under different fruit crops. Availability of fuel (wood), fodder, fruit, and small timber and food grains from the same piece of the land also increased. In that area the farmer standard of living also increased in terms of healthy food, clothing, better education, constructed a Pucca house, Pucca well and cemented irrigation channels, purchased a two wheeler vehicle and recovered from the loans took from rural bank. Jayanthi et al., (2009) revealed that integrated farming system for different conditions; enhance farm productivity, profitability and nutritional security of the farmers. And maintain the soil fertility and productivity through recycling of organic waste (of involved enterprises) that is sources of essential plant nutrients. Under the traditional cropping system, the mean of maize grain equivalent yield was about $23,542 \mathrm{~kg} / \mathrm{ha} /$ year. Whereas, under integrated farming system, the maize grain equivalent yield was about $56,885 \mathrm{~kg} / \mathrm{ha} /$ year. The net income was increased under integrated farming system as compared to traditional cropping system because of in situ recycling of resources in integrated farming system. The net return from addition of linked enterprises under integrated farming system is about Rs 150,000/ha/year and the increased income was about $43.6 \%$ over traditional cropping system. Although integrated farming system (involving cropping system and dairy) generated more man working days of employment compared with the traditional cropping system. Traditional cropping system generated 62 man working days/ha/year. While the different cropping systems under integrated farming system generated 122 man 
working day/ha/year. A maximum of 457 man working days/ha/year was generated from animal components in integrated farming system. In traditional cropping system also noticed that farm enterprises residue is very less as compared to integrated farming system. The integrated farming system of crop + milch cows + goat + bio compost and vermicompost could supply better bio resource utilization and recycling. Integrated farming system approach is better than traditional farming that is based on the farmer participatory research; with in perspective to productivity, profitability, income and employment generation for small and marginal farmers of Tamilnadu, India.
Ugwumba et al., (2010) studied the impact of integrated farming system on farm income. Maximum no. of farmers in their study area practiced limited integration of farming enterprises. And his results revealed that all types of integrated farming system combinations are more profitable over existing farming practices. The farmer net income was increased by maintained crop + livestock + fish integration. The farmers who want more income and also want to escape from poverty will target the integration of more enterprises in their farm including crops, livestock, fisheries, apiculture and even biogas (Fig. 1 and 2; Table 1 and 2).

Table.1 Increase in net returns of various farming systems due to on farm interventions in farming system approach

\begin{tabular}{|c|c|c|c|c|c|}
\hline \multirow[t]{2}{*}{ Location } & \multirow{2}{*}{$\begin{array}{l}\text { Area } \\
\text { (ha) }\end{array}$} & \multirow[t]{2}{*}{ Farming system Models } & \multicolumn{2}{|c|}{ Net returns (Rs) } & \multirow{2}{*}{$\begin{array}{l}\text { Increase } \\
(\%)\end{array}$} \\
\hline & & & \multicolumn{2}{|c|}{ Before After } & \\
\hline Kangra (HP) & 0.31 & $\begin{array}{l}\text { Crop }+ \text { dairy }+ \text { primary processing }+ \\
\text { Kitchen garden }\end{array}$ & 39942 & 61084 & 53 \\
\hline $\begin{array}{l}\text { Santkabirnagar } \\
\text { (UP) }\end{array}$ & 0.82 & crop + dairy & 28181 & 66824 & 137 \\
\hline Kakdwip (WB) & 0.61 & $\begin{array}{l}\text { Crop }+ \text { dairy }+ \text { poultry }+ \text { fisheries }+ \\
\text { secondary processing }\end{array}$ & 36344 & 55969 & 54 \\
\hline $\begin{array}{l}\text { Kabirdham } \\
\text { (CG) }\end{array}$ & 0.98 & $\begin{array}{l}\text { Crop + dairy + secondary processing } \\
+ \text { fruit + mushroom }\end{array}$ & 68843 & 103618 & 51 \\
\hline Angul (Odisha) & 0.98 & $\begin{array}{l}\text { Crop + dairy }+ \text { goat }+ \text { secondary } \\
\text { processing + kitchen garden }+ \\
\text { backyard poultry }+ \text { mushroom }\end{array}$ & 63754 & 122407 & 92 \\
\hline $\begin{array}{l}\text { Kendrapara } \\
\text { (Odisha) }\end{array}$ & 0.91 & $\begin{array}{l}\text { Crop }+ \text { dairy }+ \text { goat }+ \text { primary \& } \\
\text { secondary processing }+ \text { backyard } \\
\text { poultry }+ \text { mushroom }+ \text { Fisheries }\end{array}$ & 21074 & 34800 & 65 \\
\hline Pune (MH) & 0.90 & $\begin{array}{l}\text { Crop + dairy + primary \& secondary } \\
\text { processing + fruit }\end{array}$ & 48624 & 82724 & 70 \\
\hline $\begin{array}{l}\text { Chettinand } \\
\text { (TN) }\end{array}$ & 0.85 & $\begin{array}{l}\text { Crop + dairy + primary processing }+ \\
\text { kitchen garden + backyard poultry }\end{array}$ & 57333 & 85369 & 49 \\
\hline
\end{tabular}

Source: http//pdfsr.ernet.in/AICRP/annual/html (AICRP annual report in integrated farming system 2013-2014 
Table.2 Economic analysis of different components and system under two acre integrated farming systems module

\begin{tabular}{|l|l|l|l|l|l|l|l|}
\hline $\begin{array}{l}\text { Farming } \\
\text { System }\end{array}$ & $\begin{array}{l}\text { Rice- } \\
\text { Wheat }\end{array}$ & Vegetable & Fishery & Duckery & Cattle & $\begin{array}{l}\text { Net } \\
\text { Income } \\
\text { (Rs.) }\end{array}$ & $\begin{array}{l}\text { Employment } \\
\text { generation } \\
\text { (man days) }\end{array}$ \\
\hline Rice - Wheat & 46122 & - & - & - & - & 46122 & 402 \\
\hline $\begin{array}{l}\text { Rice - Wheat + } \\
\text { Dairy }\end{array}$ & 43815 & - & - & - & 42290 & 86105 & 550 \\
\hline $\begin{array}{l}\text { Rice - Wheat + } \\
\text { Dairy + } \\
\text { Fishery }\end{array}$ & 38050 & - & 22500 & - & 42290 & 102840 & 580 \\
\hline $\begin{array}{l}\text { Rice - Wheat + } \\
\text { Dairy +Fishery } \\
\text { + Duckery+38050 }\end{array}$ & - & & 22500 & 18000 & 42290 & 144165 & 660 \\
\hline $\begin{array}{l}\text { Rice -Wheat + } \\
\text { Vegetable + } \\
\text { Dairy }\end{array}$ & 32285 & 53790 & - & - & 42290 & 128365 & 638 \\
\hline $\begin{array}{l}\text { Rice - Wheat + } \\
\text { Vegetable + } \\
\text { dairy + Fishery }\end{array}$ & $\mathbf{3 2 2 8 5}$ & $\mathbf{5 3 7 9 0}$ & $\mathbf{2 2 5 0 0}$ & - & $\mathbf{4 2 2 9 0}$ & $\mathbf{1 5 0 8 6 5}$ & $\mathbf{6 8 0}$ \\
\hline
\end{tabular}

Source: Gender perspective in IFS, Model training course-2012-13, DAC, Ministry of Agriculture, New Delhi.

Fig.1

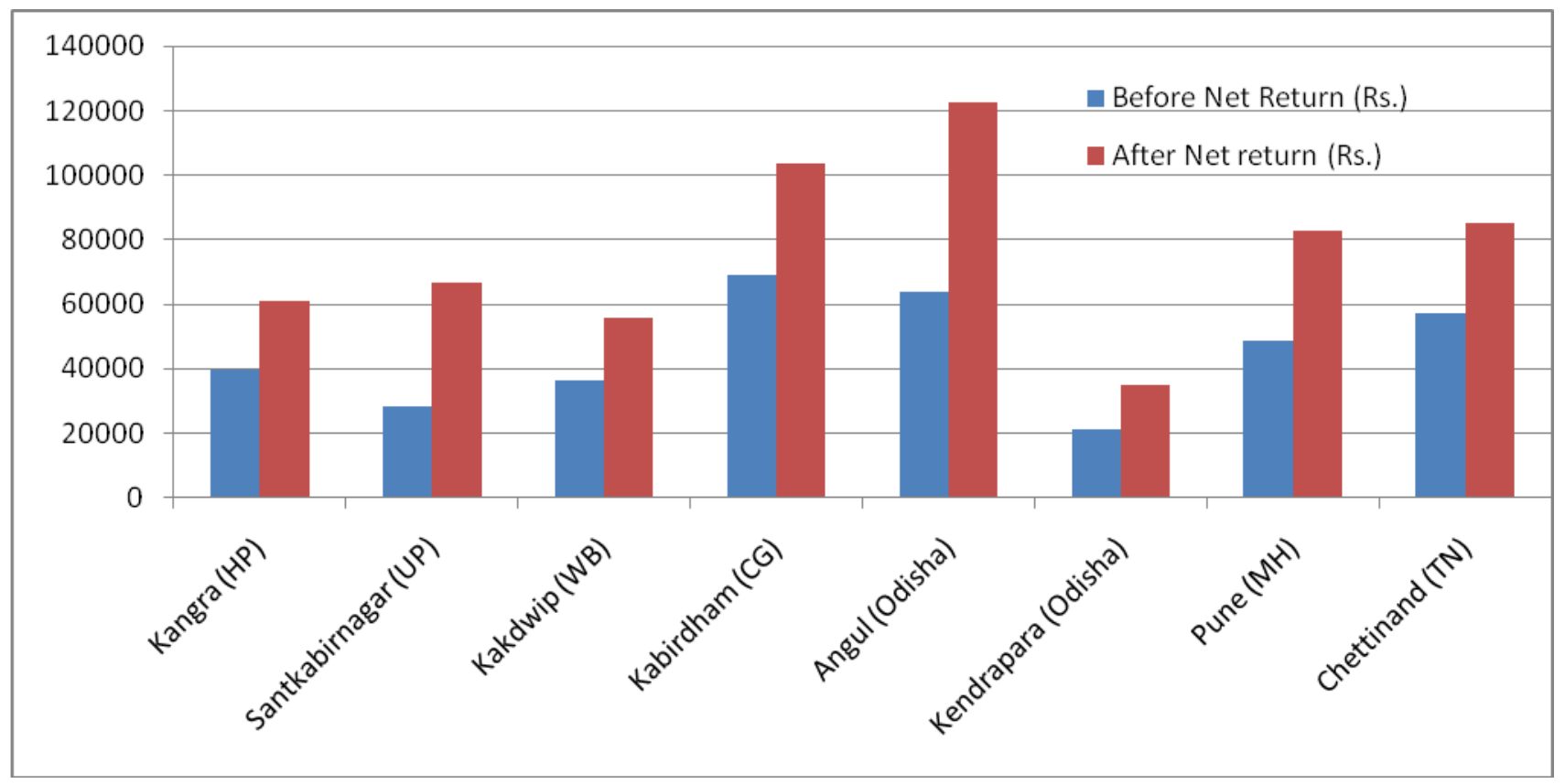


Fig.2

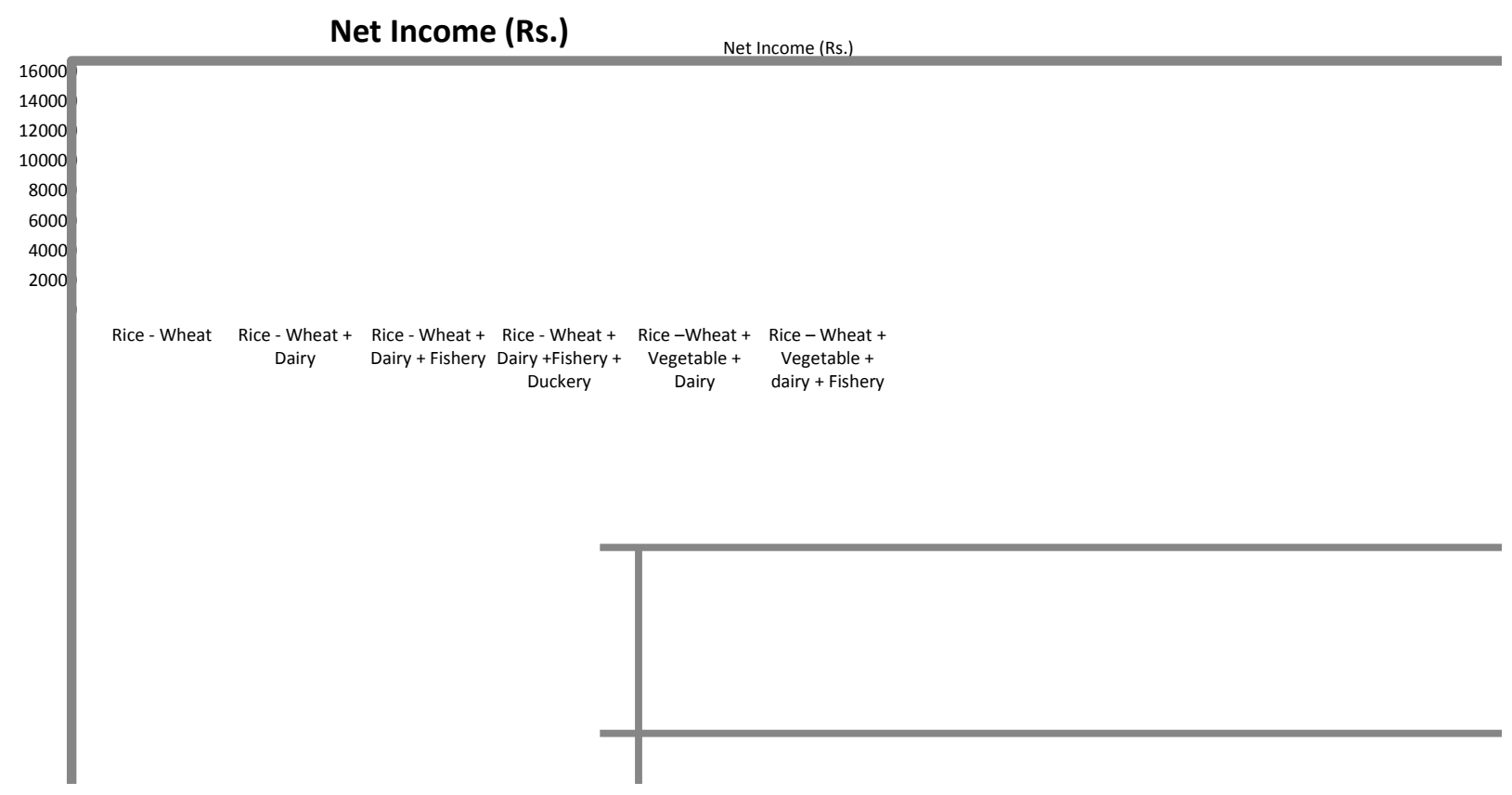

The farmer's farm cash income was positively be influenced by farmer's age, education level, years of experience and type of farm enterprises integration. However, farm cash income was negatively influenced by their household size, cost of farm inputs and gender of the farmer. The farmer's Farm cash income can also be improved by suitable policy framework and govt. farm input subsidy that will help to reduce the cost of inputs. Also increase the farmer's technical skills and their knowledge. Fraser et al., (2005) studied and concluded that the greater diversity is supposed to increase the ability of systems to withstand shocks and thereby decrease susceptibility. It was demonstrated, the temporal stability of a natural ecosystem increases with increasing the species diversity. Also, it has been suggested for agricultural system that a greater diversity can decrease vulnerability, but experimental proof is not there. Felipe (2007) showed that an about $40 \%$ of the organic farmers faced the lesser risk of market price crisis than conventional farmers. The organic farming also helps to increase the amount of organic matter in the soil. Organic farming contributes to conserve soil moisture and increased soil health. It's make organic farmers less vulnerable to the risk of drought. Likewise, more vegetative covers help to reduce the susceptibility against irradiation and frosts and weeds. It stated that organic farmers have small risk feeling than conventional farmers. Venkatadri et al., (2008) concluded that about $98 \%$ of the farmers opinion that livestock rearing reduces susceptibility in drought years, $97.8 \%$ expressed their opinion that dairy farming provides sustainable livelihoods, 97 per cent of the survey sample respondents said that farmers suicides are less in dairy farming developed areas. And commercial agriculture increased suicides rate in Andra Pradesh (96.0\%). Integrated farming system is found to be better than the traditional and commercial farming systems. In all four dimension of agriculture that is food, environmental, economic and social 
security. The findings support the concept that diversification and integration of resources on farms or integrated farming system is viable in both terms economic and ecological. The analysis shows that integrated farming system reduced the need for external inputs. High start-up or initial cost of different farm enterprises might restrict farmers to moving from traditional to integrated farming mode, and that could develop the benefits of farm resource integration. ICAR Research Complex for Eastern Patna has developed integrated farming systems modules for small and marginal farmers of Eastern region for lowland irrigated ecosystems. The details of the module are given as:

\section{Constraints in adoption of integrated farming system}

Banerjee et al., (1990) concluded that the inadequate availability of the capital as the main constraint in integrated farming system. Ngambeki et al., (1992) studied that the insufficient amount of animal feed all over the year and also unavailability of labour in peek times are the main production constraints in integrated farming system. Thamrongwarangkul (2001) revealed that the poor farmers don't have capacity to invest more amount as initial investment on various farm enterprises. When farmer need to immediate economic return from their farm to meet their food requirements, Education, Health and loan payment of bank. Tipraqsa et al., (2007) reported that the more money required at starting time for integration of various farm components and some time exploiting the benefits of resource integration for that reason farmer go away from integrated farming system. Kadam et al., (2010) revealed that the constraints of integrated farming system as high cost of concentrate feed of livestock. The unavailability of green fodder (40\% respondent), the lack of local market facilities and nonexistence of cooperative societies (30 $\%$ Respondent), $20 \%$ respondents feel lack of scientific knowledge of livestock rearing, $6 \%$ feel unavailability of improved breed of livestock and $4 \%$ expressed their view and feel lack of financial support. Poorani et al., (2011) concluded that the farmers of Palladam, Tamilnadu faced a major problem that is unavailability of sufficient quantity of fodder for their livestock in off season. Lightfoot 1997 recommended, the main constraints or limitation in adoption of integrated farming system in the Philippines and Ghana were the long evolution period that frequently occurs in implementation of integrated production system. That is labour shortages, especially in the small family. This effectively prevented in adoption of integrated farming techniques. Lack of protected land rights and discouragement also constraints them to adopt integrated farming systems. Nageswaran (2009) concluded that the many shortcomings seeming by the farmers, which are needed to be deal with and to be facilitated in, acquire superior breeds of livestock to enhance dairy related activities and the income of the farms. Also timely availability of good fish seed and fish feed, Lack of low cost and energy efficient device for pumping out irrigation water. Big gaps in spreading of information about government schemes and credit support from bank financial institutions. The farmers who implemented the integrated farming system were scattered over the region. Integrated farming system may be desirable that is collective wise integrated farming system and major group of farmers will be formed a association, that will play a very important role in solving the problems faced by the farmers and also developing the level of operation. That will help in the farmers to negotiate or access the various external institutions, and also help in organizing different training programmes for the integrated farming system farmers. 
It is concluded that, the productivity and profitability of integrated farming system is well known by the all over world. Integrated farming system can be considered for its wide spread adoption by small and marginal farmers. Reduced the size of land holdings without any alternative income enhance opportunity is slowly reducing the farm income. This factor causes the agrarian distress. A large number of small farmers have to move for nonfarm activities to supplement their income. Aims of research on integrated farming system have paid dividends, but mainly through medium and large farm holders. However, the current situation are changing and research pattern shift with more focus towards small and marginal farm holders in integrated farming systems point of view.

The role of integrated farming systems is simply overlooked when agriculture is look at by western countries eye. However, small holders may not be considered as proficient agriculture producers until a make safe market for their farm products and the consistency of income is cleared and materializes. That will only facilitate through integration of various farm enterprises. This will improve and enhance the efficiency of family labor by use of farm enterprises residues and nutrient recycling. Integration of various farm enterprises and their Potential improvements and increased their productivity. They can only come from a better understanding of the nature and capacity of the interactions among various farm enterprises and natural resources for economic benefits as well as impact of enterprises on environment and farmers livelihood. Research in the future, on these aspects of agriculture will provide major challenges for sustainable agricultural development through integrated farming systems.

\section{References}

Agbonlabor MU, Aromolaran AB, Aiboni VI. Sustainable soil management practices in small farms of Southern Nigeria: A poultry-food crop integrated farming approach. Journal of Sustainable Agriculture, 2003; 2: 51-62.

Ashby JA. Integrating research on food and the environment: An exit strategy from the rational fool syndrome in agricultural science. Ecol. Soc, 2001; 5.

Bahire VV, Kadam RP, Sidam VN. Sustainable Integrated Farming is the need of the Indian farmer. In: 22nd national seminar on "Role of Extension in Integrated Farming Systems for sustainable rural livelihood, 9th -10th Dec, Maharastra, 2010 , pp. 65.

Banerjee BN, Sarker SC, Maity AK. Impact of resource optimization on cropping pattern and income on crop-dairy mixed farm. Indian Journal of Dairy Science, 1990; 43: 295-301.

Bhalerao RA, Charge KV, Patil VG. Profile of the farmers practising the livestock based farming system: In 22nd national seminar on "Role of Extension in Integrated Farming Systems for sustainable rural livelihood, 9th -10th Dec, Maharastra, 2010. pp. 29.

Bhati TK. Integrated farming systems for sustainable agricultural on drylands. In: Sustainable Dryland Agriculture, CAZRI Publications, 1997; 102-105.

Biswas BC. Farming System Approach to Improve IUE, Employment and Income in Eastern India. Fertiliser Marketing News. 2010; 41 (5): 6-12.

Bosma RH, Udo HMJ, Verreth JAJ, Visser LE, Nam CQ. Agriculture Diversification in the Mekong Delta: Farmers' Motives and Contributions 
to Livelihoods. Asian Journal of Agriculture and Development, 2005; 2 (1\&2): 49-66.

Bosma RH, Udo HMJ, Verreth JAJ, Visser LE, Nam CQ. Agriculture Diversification in the Mekong Delta: Farmers' Motives and Contributions to Livelihoods. Asian Journal of Agriculture and Development, 2005. 2 (1\&2): 49-66.

CGIAR. Farming systems research at International Agricultural research Centres. TAC Secretariate, Rome, Italy; 1978.

Channabasavanna AS, Biradar DP, Prabhudev KN, Mahabhaleswar H. Development of profitable integrated farming system model for small and medium farmers of Tungabhadra project area of Karnataka. Karnataka J. Agric. Sci. 2009; 22(1): 25-27.

Chawla NK, Kurup MPG, Sharma VP. Animal Husbandry. State of Indian farmer. A millennium study, Department of Agriculture and Cooperation, Ministry of Agriculture, Government of India, New Delhi and Academic Foundation. New Delhi. 2004.

Csavas I. Regional review on livestock-fish production systems in Asia. In: Mukherjee TK, Moi PS, Panandam JM, Yang YS (Eds.), Proceedings of the FAO/IPT Workshop on integrated livestock-fish production systems, 1620 December 1991-1992, Institute of Advance Studies, University of Malaya, Kuala Lumpur, Malaysia.

Edwards P. Sustainable food production through aquaculture. Aquaculture Asia. Volume 2. School of Environment, Resources and Development, Asian Institute of Technology (AIT), Pathumthani, Thailand, 1997.

FAO. Recycling of organic wastes in agriculture. FAO Soil Bull., 40 Rome. 1977. pp

Faroda AS, Yadav RS, Pal RN. Comparative economics of specialized dairy farming, mixed farming and arable farming. J. Res. Har. Agric. Univ. 1978; 8: 234-39.

Food and Agriculture Organization of the United Nations. 2001. Mixed CropLivestock Farming: A Review of Traditional Technologies based on Literature and Field Experience. Animal Production and Health Papers, 152. Rome.

Gill MS, Samra JS, Singh Gurbachan. Integrated farming system for realizing high productivity under shallow water-table condtions. Research bulletins, Department of Agronomy, PAU, Ludhiana, 2005, 129.

Gulati H, Singh KP, Singh SN, Kadian VS, Dahiya SS. Comparative productivity and economics of dairy enterprises under mixed farming systems. Haryana Agric. Univ. J. Res. 1994; 20: $186-190$

Itnal CJ, Hundekar ST, Warad SM, Itnal MC. Farming system -a rational approach for sustainable agriculture, pp. 53-73. In. Lecture notes of summer short course on Farming System for sustainable production, Univ. Agric. Sci., Dharwad, 24th May to 2nd June, 1999.

Jagadeeshwara K, Nagaraju Y, Bhagyavathi, Nagaraju K. Livelihood improvement of vulnerable farmers through Integrated Farming Systems of Southern Karnataka, 2011; 145 -146.

Jayanthi C, Baluswamy M, Chinnusamy C, Mythily S. Integrated nutrient supply system of linked components in lowland integrated farming system. Indian Journal of Agronomy. 2003; 48: $241-246$ 
Jayanthi C, Rangasamy A, Chinnusammy C, Purushothaman S, Planiappan SP. Integrated farming systems for smallholdings. Indian Journal of Agronomy. 1994; 39:1-7.

Jayanthi C, Rangasamy A, Chinnusamy C. Water budgeting for components in lowland integrated farming systems. Agricultural Journal. 2000; 87:411414.

Jayanthi C. Integrated farming system: A path to sustainable agriculture. 2nd edition, Published by department of Agronomy, Directorate of Soil and Crop management studies, Tamilnadu Agricultural University, Coimbatore, $2006 ; 1$.

Jitsanguan T. Sustainable agriculture systems for small scale farmers in Thailand: implications for the environment. Available at: http://www.agnet.org/library/eb/509/ (Accessed 1 February, 2012).

Kadam SS, Hatey AA, Nikam TR, Landge SP, Palampalley HY. Constraints of IFS in Kankan region of Maharashtra A case study. In: 22nd national seminar on "Role of Extension in Integrated Farming Systems for sustainable rural livelihood, 9th -10 th Dec 2010; 101.

Korikanthimath VS, Manjunath BL. Resource use efficiency in integrated faming systems. In: Proceeding of A symposium on Alternative Farming systems: Enhanced income and employment generation options for small and marginal farmers PDCSR, Modipuram, 2005; 109-118

Lal R, Miller FP. Sustainable farming for tropics. In: Sustainable agriculture: Issues and Prospective. Vol. 1 (Ed.) R.P. Sing, Indian Society of Agronomy, IARI, New Delhi.1990; 69-89,

Mahadik RP, Bhairamkar MS, Desai AN.
Profile of the farmers practicising the backyard poultry farming system. In: 22nd national seminar on "Role of Extension in Integrated Farming Systems for sustainable rural livelihood, 9th -10th Dec, Maharastra,; 2010; 30-31.

Manivannan A, Mathialagan P, Narmatha N. Goat based farming system in Tamilnadu, 2011; 163.

Manjunath BL, Itnal CJ. Farming system options for small and marginal holdings in different topographies of Goa. Indian Journal of Agronomy. 2003; 48 (1): 4-8

Mohanty D, Patnaik SC, Jeevan Das P, Parida NK, Nedunchezhiyan M. Sustainable livelihood:a success story of a tribal farmer. Orissa Review, September: 2010; 4143.

Nageswaran M, Selvaganapathy E, Subbiah VR, Nair S. Demonstration and Replication of Integrated Farming Systems at Chidambaram. Report of M.S. Swaminathan Research Foundation (MSSRF), Chennai,2009; $16-53$.

Narain P, Bhati TK. Alternative Farming system: Issue and opportunities in arid ecosystem. In: Proceeding, National Symposium on Alternative Farming Systems held at PDCSR, Modipuram, 16-18 September, 2004, 2005; 57-64

Ngambeki DS, Deuson RR, Preckel PV. Integrating livestock into farming systems in northern Cameroon. Agricultural Systems. 1992; 38: 319338.

Nhan DK, Phong LT, Verdegem MJC, Duong LT, Bosma RH, Little DC. Integrated freshwater aquaculture, crop and animal production in the Mekong Delta, Vietnam: determinants and the role of the pond. Agricultural system. 2007; 94:445-458.

Okigbo BN. Major farming systems of the 
lowland savanna of SSA and the potential for improvement. In: Proceedings of the IITA/FAO workshop, Ibadan, Nigeria, 1995.

Panke SK, Kadam RP, Nakhate CS. Integrated Farming System for sustainable rural livelihood security. In: 22nd national seminar on "Role of Extension in Integrated Farming Systems for sustainable rural livelihood, 9th -10th Dec, Maharastra, 2010; 33-35.

Phong LT, Tri LQ, Udo HMJ, Nhan DK, van Mensvoort MEF, van der Zijpp AJ, Bosma RH. Integrated agricultureaquaculture systems in the Mekong delta, Vietnam: an analysis of recent trends. Asian Journal of Agriculture and Development. 2008; 4: 51-66.

Poorani A, Jayanthi C, Vennila C. Farmer participatory research on Integrated Farming Systems. In: National seminar on "Innovations in farming systems research and extension for inclusive development" 24 -25 Nov, Madras Veterinary College, Chennai, 2011; 153 .

Prasad SC, Lakra V, Prasad C. Integrated Farming Systems for enhancing sustainable rural livelihood security in Sahibganj and Pakur Districts of Jharkhand. In: International conference on innovative approaches for agriculture knowledge management global extension experiences, 9th -12th Nov, National Agricultural Science Complex, New Delhi, India, 2011.

Prein M. Integration of aquaculture into crops-animal systems in Asia. Agricultural system. 2002; 71: 127146.

Radha Y, Eshwara Prasad Y, Vijayabhinandana B. Study on income and employment generation on agricultural based livestock farming systems. Paper presented at VIII Annual Conference of AERA at TNUASU, Chennai, 28-29 December, 2000.

Radhamani S, Balasubramanian A, Ramamoorthy K, Geethalakshmi V. Sustainable integrated farming systems for dry lands: A review. Agricultural Reviews. 2003; 24: 204210.

Raman KV, Balaguru T. Farming Systems Research in India: Strategies for implementation. Proceedings of the National Workshop, November 25-28, 1991, NAARM, Hyderabad, India, 1992.

Ramasamy, C., Natarajan, S., Jayanthi, C and Kumar, D. S. 2008. Intensive Integrated Farming System to boost income of farmers. Paper presented in the 32nd IAUN VC's Annual convention held at RAU, Ranchi.

Ramrao WY, Tiwari SP, Singh P. Croplivestock integrated farming system for augmenting socio-economic status of smallholder tribal of Chhattisgarh in central India. Livestock Research for Rural development. 2005; 17(90).

Ramrao WY, Tiwari SP, Singh P. Croplivestock integrated farming system for the Marginal farmers in rain fed regions of Chhattisgarh in Central India. Livestock Research for Rural Development, 2006; 8 (7).

Rangaswamy A, Venkatswamy R, Premshekhar M, Jayanthi C, Palaniappan SP. Integrated farming systems for rice based ecosystem. Madras Agricultural Journal. 1996; 1 82(4): 290-293.

Ravishankar, Pramanik N, Rai SC, Shakila Nawaz, Tapan RB, Biswas KR, Nabisat B. Study on integrated farming system in hilly upland areas of Bay Islands. Indian Journal of Agronomy. 2007; 52: 7-10. 
Ray DP. Livelihood security in rice - based farming systems. In: Invited papers and abstracts. National seminar on managing livelihood in India: Challenges and opportunities, DAT, Bhubaneswar, 2009.

Sanjeev Kumar, Singh SS, Dey A, Shivani. Integrated farming systems for Eastern India Indian Journal of Agronomy. 2011; 56(4): 297-304.

Sanjeev Kumar, Singh SS, Meena MK, Shivani, Dey A. Resource recycling and their management under integrated farming system for lowlands of eastern India. Indian Journal of Agricultural sciences. 2012; 82(6).

Sanjeev Kumar, Subhash N, Shivani, Singh SS, Dey A. Evaluation of different components under Integrated farming system (IFS) for small and marginal farmers under semi-humid climatic environment. Experimental Agriculture, 2012; 48 (3): 399-413.

Sethi RK. Live stock production in various farming systems of Haryana. Proc. summer institute on integrated farming systems for small and marginal farmers, CCSHAU, Hisar, India. 1991; II. 556-557.

Shaner WW, Phillip PE, Schmehl WR. Farming system research and development guidelines for developing countries. West view Press, Boulder, and Colarado, USA. 1982.

Singh CB, Renkema JA, Dhaka JP, Singh Keran, Schiere JB.(1993) Income and employment on small farmers. In: Proceeding An International workshop on Feeding of Ruminants on fibrous crop residues: Aspects of Treatment, Feeding, nutrient evaluation, research and extension. Karnal, Haryana, 4-8 February, 1991, pp. 67-76.

Singh DP, Singh KP, Yadavika. Integrated farming system - a key issue for research-education-extension linkages. Proc. First International Agronomy Congress - Agronomy, 23-27 November, 1998, New Delhi, India. p 474-488.

Singh GD, Chhiber SS. Is dairy profitable in India. Indian Dairyman. 1971; 23: $149-50$

Singh Gurbachan. Farming systems options in sustainable management of national resources. In: Proceedings National Symposium on Alternative Farming Systems held at PDCSR, Modipuram, 16-18 September, 2004; 80-94.

Singh KP, Kadian VS, Kumar H, Saxena KK, Singh SN, Kumar V. Integrated farming systems for optimising resource use under small holding conditions of Haryana. Haryana $\mathbf{J}$. Agron. 1994; 10: 43-47.

Singh KP, Singh SN, Kumar H, Kadian VS, Saxena KK. Economic analysis of different farming systems followed on small and marginal land holdings in Haryana. Haryana Journal of Agronomy, 1993; 9: 122-125.

Singh KP, Singh SN, Kumar H, Kadian VS, Saxena KK. Economic analysis of different farming systems followed on small and marginal land holdings in Haryana. Haryana Journal of Agronomy. 1993; 9: 122-125.

Singh KP, Singh SN, Kumar H, Kadian VS, Saxena KK. Economic analysis of different farming systems followed on small and marginal land holdings in Haryana. Haryana Journal of Agronomy. 1993; 9: 122-125.

Singh KP. Integrated farming systems approach - concepts \& scope. In resource management and crop productivity. Haryana Agronomists Association, Department of Agronomy, CCS HAU, Hisar, 1994; 69-85. 
Singh KP. Integrated farming systems for small holders - A key issue for research-education-extension linkages in semi-arid tropical conditions. Paper submitted to $17^{\text {th }}$ Symposium of the International Farming Association, Nov. 17-20, 2002 Orlando, Florida, USA.

Singh Rajender, Singh Narinder, Phogat SB, Sharma UK, Singh R, Singh N. Income and employment potential of different farming system. Haryana Agricultural University Journal of Research. 1999; 29 (3-4): 143-145.

Singh RP, Ratan. Farming system approach for growth in Indian Agriculture. Lead paper in: National seminar on Enhancing efficiency of Extension for sustainable agriculture and livestock production, Dec 29- 30,2009, Indian Veterinary Research Institute, Izatnagar.

Singh SN, Saxena KK, Singh KP, Kumar H, Kadian VS. Consistency in income and employment generation in various farming systems. Annals of Agricultural Research. 1997; 18(3): 340-43.

Sushil Kumar Patial, Impacts of Green Revolution, Pp. 2.

Thamizoli PR, Rengalakshmi K, Senthilkumar, Selvaraju T. Agronomic Rehabilitation and Livelihood Restoration of Tsunami Affected Lands in Nagapattinam District of Tamil Nadu. M.S. Swaminathan Research Foundation Chennai, 2006; 31.

Thamrongwarangkul, A. For out Thailand. Annual report on sustainable community development for good livelihoods and environmental project. Khon Kaen University, 2001.

Thankur RC, Badiyala D. Farming systems issues and opportunities in northwestern Himalayas. In: Proceeding
National Symposium on 'Alternative Farming Systems, 2005; $72-79$ (Eds: A.K. Singh, B. Gangwar and S.K. Sharma). Project Directorate For Farming Systems Research, Modipuram.

Tipraqsa P, Craswell ET, Noble AD, Schmidt VD. Resource integration for multiple benefits: multifunctionality of integrated farming systems in Northeast Thailand. Agricultural Systems. 2007; 94: 694-703.

Tomer SP, Sai Ram RK, Harika AS, Ganguly TK. Comparative efficiency of dairy and mixed farming systems. Forage Research. 1982; 8: 93-98.

Tripathi H, Tomar SS, Pandey R, Solanki VS, Singh R, Meena KL, Tomar M, Adhikari DS. Economic feasibility of Integrated Farming System models with respect to productivity and economics. In: 22nd national seminar on "Role of Extension in Integrated Farming Systems for sustainable rural livelihood, 9th -10th Dec, Maharashtra, 2001; pp. 42-43.

Tripathi SC, Rathi RC. Livestock farming system module for hills. In: Souvenir. National symposium on technological interventions for sustainable agriculture, 3rd - 5th May, GBPUAT, hill campus, Ranichuri, 2011; 103 104.

Van Brakel ML, Morales EJ, Turingruang D, Little DC. Livelihood improving functions of pond based integrated agriculture and aquaculture systems. MRC Fisheries Programme (FP). Institute of Aquaculture, University of Stirling, Scotland, UK, 2003.

Veerabhadraiah. Technological interventions and productivity of small farms. Unpublished research project report. UAS. Bangalore, 2007.

Virozi Rao ST, Bose SC. Integrated Farming System approaches for Sustainable 
Agriculture'.2002, Presented at $32^{\text {nd }}$ Research and extension advisory council meeting of ANFR Agricultural University, Rajendranagar, Hyderabad, 26-27 December, 2007.

Vision 2020,. KVK. Assam agricultural
University, Darrang, Mangaldai, 2011; pp. $159-160$.

Vision 2030, Central Soil Salinity Research Institute (CSSRI), Karnal, 2011d; pp. 15.

\section{How to cite this article:}

Anil Kumar Yadav, Ramawat Nalini and Singh Dashrath. 2019. Integrated Farming Systems Approach: Increase Food Security, Agricultural Farm Income and Rural Economy. Int.J.Curr.Microbiol.App.Sci. 8(02): 1167-1185. doi: https://doi.org/10.20546/ijcmas.2019.802.136 